\title{
Protocol: A two-wave cross-sectional study in England investigating suicidal behaviour and self-harm amongst healthcare workers during the Covid-19 pandemic
}

\author{
Prianka Padmanathan* ${ }^{1}$, Danielle Lamb ${ }^{2}$, Hannah Scott ${ }^{3}$, Simon Wessely $^{3}$, Paul Moran $^{1,4,5}$ \\ ${ }^{1}$ Population Health Sciences, Bristol Medical School, University of Bristol, Bristol, UK \\ ${ }^{2}$ The National Institute for Health Research Applied Research Collaboration North Thames (NIHR \\ ARC North Thames), University College London, London, UK \\ ${ }^{3}$ Institute of Psychiatry, Psychology and Neuroscience, King's College London, London, UK \\ ${ }^{4}$ National Institute of Health Research Biomedical Research Centre at the University Hospitals, \\ Bristol and Weston NHS Foundation Trust and the University of Bristol, Bristol, UK \\ ${ }^{5}$ The National Institute for Health Research Applied Research Collaboration West (NIHR ARC West), \\ Bristol, UK \\ *Corresponding author: prianka.padmanathan@bristol.ac.uk
}

\begin{abstract}
Introduction

There have been longstanding concerns regarding an increased risk of suicide amongst healthcare workers. The Covid-19 pandemic has placed an additional burden on staff, yet few studies have investigated the impact of the pandemic on their risk of suicide and selfharm. We aimed to investigate the cumulative incidence, prevalence and correlates of suicidal ideation, suicide attempts and non-suicidal self-injury amongst healthcare workers during the Covid-19 pandemic.
\end{abstract}

\section{Methods and Analysis}

NHS Check is an online survey that was distributed to all staff (clinical and non-clinical), students, and volunteers in 18 NHS Trusts across England during the Covid-19 pandemic. Data collected in wave 1 (collected between April 2020 and January 2021) and wave 2 (collected 6-month after wave 1) will be analysed. The full cohort of wave 1 participants will be weighted to represent the age, sex, ethnicity, and roles profile of the workforce at each Trust, and the weighted prevalence and cumulative incidence of suicidal ideation, suicide attempts and non-suicidal self-injury will be described. Two-level random effects logistic regression models will be used to investigate the relationship between suicidal behaviour and self-harm, and demographic characteristics (age, sex, ethnicity) and workplace factors (concerns regarding access to personal protective equipment, re-deployment status, moral injury, confidence around raising and the management of safety concerns, support by supervisors or managers, satisfaction with standard of care provided). Results will be stratified by role (clinical/non-clinical). 
medRxiv preprint doi: https://doi.org/10.1101/2021.09.16.21263255; this version posted September 21, 2021. The copyright holder for this preprint (which was not certified by peer review) is the author/funder, who has granted medRxiv a license to display the preprint in perpetuity.

It is made available under a CC-BY-NC-ND 4.0 International license .

\section{Introduction}

There have been longstanding concerns regarding an increased risk of suicide amongst healthcare workers ${ }^{1,2}$. The Covid-19 pandemic has placed an additional burden on healthcare staff, yet while several studies have investigated the impact of the pandemic on their mental health ${ }^{3-7}$, few have investigated their risk of suicide and self-harm ${ }^{8}$.

Provisional Office of National Statistics data indicate that there has been an increase in the absolute number of suicides, and the proportion of total deaths that were due to suicide, amongst health workers in England and Wales in the first six months of 2020 compared to the same period in $2019^{9}$. Occupational exposures such as inadequate support from colleagues and moral injury have previously been linked with suicidal ideation and suicide attempts ${ }^{10}$, although, to date, the latter has only been investigated in a small number of studies of military personnel ${ }^{11}$. Amongst healthcare workers working in epidemics, several modifiable occupational risk factors, such as a lack of specialised training or personal protective equipment, have been associated with worse mental health ${ }^{6,12}$.

\section{Aims \& objectives}

To investigate the cumulative incidence, prevalence and correlates of non-fatal suicidal behaviour (i.e. suicidal ideation and suicide attempts) and self-harm (i.e. non-suicidal selfinjury) amongst healthcare workers during the Covid-19 pandemic.

1) Describe the prevalence of suicidal ideation, suicide attempts and non-suicidal selfinjury at baseline and at 6 months follow-up

2) Describe the cumulative incidence of suicidal ideation, suicide attempts and nonsuicidal self-injury at 6 months follow-up

3) Investigate the relationship between demographic characteristics and workplace factors reported at baseline and suicidal ideation, suicide attempts and self-harm at baseline and at 6 months follow-up.

\section{Methods}

NHS Check is multi-wave online survey that was distributed to all staff (clinical and nonclinical), students, and volunteers in 18 NHS Trusts across England during the Covid-19 pandemic ${ }^{13}$. Data from the 17 Trusts (those with a response rate of over $5 \%$ ) will be included in this analysis. Data for wave 1 were collected between April 2020 and January 2021. Data for wave 2 were collected six months after each participants' completion of the wave 1 survey. Both waves included a "short" survey and a "long" survey. Participants could choose to complete either the "short" survey alone or complete the "long" survey in addition. In wave 1, the "short" survey collected demographic information, whilst the "long" survey included questions relating to the workforce factors and the suicide and selfharm outcomes described in this study. In wave 2 , questions relating to suicide and selfharm were included in the "short" survey. Further details regarding data collection can be found elsewhere ${ }^{13}$. 


\section{Outcomes}

Suicidal ideation, suicide attempts and non-suicidal self-injury were assessed using the following items from the Clinical Interview Schedule (CIS-R) ${ }^{14}$ : "Have you ever thought of taking your life, even though you would not actually do it?"; "Have you ever made an attempt to take your life, by taking an overdose of tablets or in some other way?"; and "Have you ever deliberately harmed yourself in any way but not with the intention of killing yourself?". In the baseline survey, participants could select from the following options: "Yes, in the past 2 months", "Yes, but not in the past 2 months", or "No". In the 6-month followup survey, participants could select from the same options but a one, rather than two, month time frame was specified.

\section{Explanatory factors}

\section{Demographic characteristics}

Variables will be defined as follows based on previous NHS Check analyses ${ }^{8}$ :

- Age

- Sex (Female, male - options are limited by survey design)

- Ethnicity (ONS top level categories: white, black, Asian, mixed ethnicity, other ethnicity)

- Role (Doctor, nurse, other clinical, non-clinical)

\section{Individual level workplace factors}

The following factors will be analysed as binary exposures (see Appendix for questions):

- Concerns re. access to personal protective equipment (Q85 short survey: never/sometimes to be categorised as 'lack of access to PPE'; often/always to be categorised as 'adequate access to PPE')

- Re-deployment status (Q69 short survey: yes/no)

- Moral injury (Q50 long survey: moderately agree/strongly agree to be categorised as 'exposure to potentially morally injurious events')

The following factors will be analysed as ordered categorical exposures on a 5-point scale, where 1 will represent a negative response, and 5 will represent a positive response.

- Confidence around raising and the management of safety concerns (Q19 long survey: combining both sub-questions)

- Support by supervisors or managers (Q87b short survey)

- Satisfaction with standard of care provided - worse care than usual (Q11b long survey) - clinical staff only

\section{Statistical analysis}

The full cohort (i.e. those completing the short survey at wave 1) will be weighted using a ranking algorithm based on the age, sex, ethnicity, and roles profile of the workforce at each Trust to maximise representativeness. To complete the weighting, missing demographic data will be imputed using multiple imputation. The imputed data will only be used for the purposes of completing weighting and will not be used in any other analyses related to the aims and objectives, which will only include participants with complete data on the included 
variables. Some participants completed the baseline survey more than once. The weighting includes an average of these participants' responses.

We will describe the demographic and occupational characteristics of the full cohort, our wave 1 sub-sample (i.e. those who completed the suicide and self-harm questions in the wave 1 long survey), and our wave 2 sub-sample (i.e. those who completed the suicide and self-harm questions in the wave 2 short survey) (Table 1). We will compare our sub-samples to the full cohort, using $\mathrm{Chi}^{2}$ tests for each binary or categorical variable, to assess any statistically significant differences between the groups.

We will describe the weighted prevalence of our outcomes for participants at wave 1 and at wave 2 (Table 2). Due to the discrepancy in the time frames specified by the suicide and selfharm questions between waves, a 2-month period prevalence will be calculated for wave 1 , whilst a 1-month period prevalence will be calculated for wave 2 . We will also describe the weighted cumulative incidence of our outcomes at wave 2 i.e. the number and percentage of participants who responded "no" to previous self-harm and suicidal behaviour at wave 1 , but "yes" at wave 2 (Table 2).

Given the clustered nature of the data, we will then use two-level random effects logistic regression models to investigate the relationship between each demographic characteristic and workplace factor reported at wave 1 and suicidal behaviour and self-harm at wave 1 and wave 2 (Tables 3 and 4). Data will be stratified by role (clinical/non-clinical). Participants (level 1) will be clustered within each Trust (level 2), and we will adjust for age, sex, ethnicity and date of survey completion as level 1 co-variates. When analysing the outcomes at wave 2 , in addition, we will also adjust for the corresponding outcome at wave 1 (level 1). For example, when analysing suicidal ideation at wave 2 , we will adjust for suicidal ideation at wave 1 . In each model, we will only include participants with complete data on all included variables. We will use the "subpop" command in Stata to ensure that the standard errors of the estimates are calculated correctly ${ }^{16}$.

Ethics

Ethics and Dissemination Ethical approval for the NHS Check study was granted by the Health Research Authority (reference: 20/HRA/210, IRAS: 282686) and local Trust Research and Development approval. See elsewhere for further details ${ }^{13}$. 
Table 1: Survey sample characteristics

\begin{tabular}{|c|c|c|c|c|}
\hline \multirow[t]{2}{*}{ Variable } & \multirow[t]{2}{*}{ Category } & \multicolumn{3}{|c|}{ No. (\%) unless otherwise specified } \\
\hline & & Full cohort & Wave 1 sample & Wave 2 sample \\
\hline Age in years & Median (IQR) & & & \\
\hline \multirow[t]{2}{*}{ Sex } & Female & & & \\
\hline & Male & & & \\
\hline \multirow[t]{5}{*}{ Ethnicity } & White & & & \\
\hline & Black/African/Caribbean/Black British & & & \\
\hline & Asian/Asian British & & & \\
\hline & Mixed/Multiple racial and ethnic groups & & & \\
\hline & Other racial and ethnic minority groups & & & \\
\hline \multirow[t]{4}{*}{ Role } & Doctor & & & \\
\hline & Nurse & & & \\
\hline & Other clinical & & & \\
\hline & Non-clinical & & & \\
\hline \multirow[t]{2}{*}{ Concerns about access to PPE } & No & & & \\
\hline & Yes & & & \\
\hline \multirow[t]{2}{*}{ Redeployment } & No & & & \\
\hline & Yes & & & \\
\hline Support from managers & Median score ${ }^{+}(\mathrm{QQR})$ & & & \\
\hline Satisfaction with standard of care provided & Median score ${ }^{+}(\mathrm{QQR})$ & & & \\
\hline Confidence around raising and management of safety concerns & Median score ${ }^{+}$(IQR) & & & \\
\hline \multirow[t]{2}{*}{ Moral injury } & No & & & \\
\hline & Yes & & & \\
\hline
\end{tabular}

${ }^{+}$Scored out of 5 (1=negative $; 5=$ positive $)$ 
Table 2: Prevalence and incidence of suicidal behaviour and self-harm

\begin{tabular}{|c|c|c|c|c|c|c|c|c|}
\hline & \multirow[b]{2}{*}{ Response } & & \multicolumn{3}{|c|}{ Prevalence* } & \multicolumn{3}{|c|}{ Cumulative incidence } \\
\hline & & & $\begin{array}{l}\text { Suicidal } \\
\text { ideation }\end{array}$ & $\begin{array}{l}\text { Suicidal } \\
\text { attempts }\end{array}$ & $\begin{array}{l}\text { Non-suicidal } \\
\text { self-injury }\end{array}$ & $\begin{array}{l}\text { Suicidal } \\
\text { ideation }\end{array}$ & $\begin{array}{l}\text { Suicidal } \\
\text { attempts }\end{array}$ & $\begin{array}{l}\text { Non-suicidal } \\
\text { self-injury }\end{array}$ \\
\hline \multirow{3}{*}{$\begin{array}{c}\text { Wave } \\
1\end{array}$} & No & $\begin{array}{c}n(\%) \\
{[95 \% \mathrm{Cl}]}\end{array}$ & & & & $N / a$ & $\mathrm{~N} / \mathrm{a}$ & $\mathrm{N} / \mathrm{a}$ \\
\hline & $\begin{array}{l}\text { Yes, but not in the } 2 \text { months prior to } \\
\text { wave } 1 \text { survey completion }\end{array}$ & $\begin{array}{c}n(\%) \\
{[95 \% \mathrm{Cl}]}\end{array}$ & & & & $\mathrm{N} / \mathrm{a}$ & $\mathrm{N} / \mathrm{a}$ & $\mathrm{N} / \mathrm{a}$ \\
\hline & $\begin{array}{c}\text { Yes, in the } 2 \text { months prior to wave } 1 \\
\text { survey completion }\end{array}$ & $\begin{array}{c}n(\%) \\
{[95 \% \mathrm{Cl}]}\end{array}$ & & & & $\mathrm{N} / \mathrm{a}$ & $\mathrm{N} / \mathrm{a}$ & $\mathrm{N} / \mathrm{a}$ \\
\hline \multirow{3}{*}{$\begin{array}{c}\text { Wave } \\
2\end{array}$} & No & $\begin{array}{c}n(\%) \\
{[95 \% \mathrm{Cl}]}\end{array}$ & & & & & & \\
\hline & $\begin{array}{c}\text { Yes, but not in the month prior to wave } 2 \\
\text { survey completion }\end{array}$ & $\begin{array}{c}n(\%) \\
{[95 \% \mathrm{Cl}]}\end{array}$ & & & & & & \\
\hline & $\begin{array}{l}\text { Yes, in the month prior to wave } 2 \text { survey } \\
\text { completion }\end{array}$ & $\begin{array}{c}n(\%) \\
{[95 \% \mathrm{Cl}]}\end{array}$ & & & & & & \\
\hline
\end{tabular}

$\mathrm{n}=$ frequency (unweighted); proportions are weighted

*Wave 1=2-month period prevalence; Wave $2=1$-month period prevalence 
Table 3: Association between demographic characteristics in relation to suicidal behaviour and self-harm at wave 1 and wave 2

\begin{tabular}{|c|c|c|c|c|c|c|c|c|c|c|c|c|c|}
\hline \multirow{3}{*}{ Variable } & \multirow{3}{*}{ Category } & \multicolumn{6}{|c|}{ Wave 1} & \multicolumn{6}{|c|}{ Wave 2} \\
\hline & & \multicolumn{2}{|c|}{$\begin{array}{l}\text { Suicidal ideation } \\
\text { (aOR; } 95 \% \mathrm{Cl} \text { ) }\end{array}$} & \multicolumn{2}{|c|}{$\begin{array}{c}\text { Suicide } \\
\text { attempts } \\
\text { (aOR; } 95 \% \mathrm{Cl} \text { ) }\end{array}$} & \multicolumn{2}{|c|}{$\begin{array}{l}\text { Non-suicidal } \\
\text { self-injury } \\
\text { (aOR; } 95 \% \mathrm{Cl} \text { ) }\end{array}$} & \multicolumn{2}{|c|}{$\begin{array}{l}\text { Suicidal ideation } \\
\text { (a OR; } 95 \% \mathrm{Cl})\end{array}$} & \multicolumn{2}{|c|}{$\begin{array}{c}\text { Suicide } \\
\text { attempts } \\
\text { (aOR; } 95 \% \mathrm{Cl})\end{array}$} & \multicolumn{2}{|c|}{$\begin{array}{l}\text { Non-suicidal } \\
\text { self-injury } \\
(\mathrm{aOR} ; 95 \% \mathrm{Cl})\end{array}$} \\
\hline & & Clinical & $\begin{array}{l}\text { Non- } \\
\text { clinical }\end{array}$ & Clinical & $\begin{array}{l}\text { Non- } \\
\text { clinical }\end{array}$ & Clinical & $\begin{array}{l}\text { Non- } \\
\text { clinical }\end{array}$ & Clinical & $\begin{array}{l}\text { Non- } \\
\text { clinical }\end{array}$ & Clinical & $\begin{array}{l}\text { Non- } \\
\text { clinical }\end{array}$ & Clinical & $\begin{array}{l}\text { Non- } \\
\text { clinical }\end{array}$ \\
\hline $\begin{array}{l}\text { Age in } \\
\text { years }\end{array}$ & Median (IQR) & & & & & & & & & & & & \\
\hline \multirow{2}{*}{ Sex } & Female (Ref) & & & & & & & & & & & & \\
\hline & Male & & & & & & & & & & & & \\
\hline \multirow{5}{*}{ Ethnicity } & White (Ref) & & & & & & & & & & & & \\
\hline & $\begin{array}{l}\text { Black/African/Caribbean/Black } \\
\text { British }\end{array}$ & & & & & & & & & & & & \\
\hline & Asian/Asian British & & & & & & & & & & & & \\
\hline & $\begin{array}{l}\text { Mixed/Multiple racial and } \\
\text { ethnic groups }\end{array}$ & & & & & & & & & & & & \\
\hline & $\begin{array}{l}\text { Other racial and ethnic } \\
\text { minority groups }\end{array}$ & & & & & & & & & & & & \\
\hline
\end{tabular}

aOR: adjusted odds ratios: adjusted for age, sex, ethnicity, and date of survey completion (6-month data also adjusted for corresponding outcome measured at baseline); $\mathrm{Cl}$ : confidence intervals 
Table 4: Association between baseline workplace factors and suicidal behaviour and self-harm at wave 1 and wave 2

\begin{tabular}{|c|c|c|c|c|c|c|c|c|c|c|c|c|c|}
\hline \multirow{3}{*}{ Variable } & \multirow{3}{*}{ Category } & \multicolumn{6}{|c|}{ Wave 1} & \multicolumn{6}{|c|}{ Wave 2} \\
\hline & & \multicolumn{2}{|c|}{$\begin{array}{l}\text { Suicidal ideation } \\
\text { (aOR; } 95 \% \mathrm{Cl} \text { ) }\end{array}$} & \multicolumn{2}{|c|}{$\begin{array}{l}\text { Suicide attempts } \\
\text { (aOR; } 95 \% \mathrm{Cl} \text { ) }\end{array}$} & \multicolumn{2}{|c|}{$\begin{array}{l}\text { Non-suicidal self- } \\
\text { injury } \\
\text { (aOR; } 95 \% \mathrm{Cl} \text { ) }\end{array}$} & \multicolumn{2}{|c|}{$\begin{array}{l}\text { Suicidal ideation } \\
\text { (aOR; } 95 \% \mathrm{Cl} \text { ) }\end{array}$} & \multicolumn{2}{|c|}{$\begin{array}{l}\text { Suicide attempts } \\
\text { (aOR; } 95 \% \mathrm{Cl})\end{array}$} & \multicolumn{2}{|c|}{$\begin{array}{l}\text { Non-suicidal self- } \\
\text { injury } \\
(\text { aOR; } 95 \% \mathrm{Cl} \text { ) }\end{array}$} \\
\hline & & Clinical & $\begin{array}{l}\text { Non- } \\
\text { clinical }\end{array}$ & Clinical & $\begin{array}{l}\text { Non- } \\
\text { clinical }\end{array}$ & Clinical & $\begin{array}{l}\text { Non- } \\
\text { clinical }\end{array}$ & Clinical & $\begin{array}{l}\text { Non- } \\
\text { clinical }\end{array}$ & Clinical & $\begin{array}{l}\text { Non- } \\
\text { clinical }\end{array}$ & Clinical & $\begin{array}{l}\text { Non- } \\
\text { clinical }\end{array}$ \\
\hline \multirow[t]{2}{*}{ Concerns about access to PPE } & No (Ref) & & & & & & & & & & & & \\
\hline & Yes & & & & & & & & & & & & \\
\hline \multirow[t]{2}{*}{ Redeployment } & No (Ref) & & & & & & & & & & & & \\
\hline & Yes & & & & & & & & & & & & \\
\hline Support from managers & $\begin{array}{l}\text { Median } \\
\text { score }^{+}(I Q R)\end{array}$ & & & & & & & & & & & & \\
\hline $\begin{array}{l}\text { Satisfaction with standard of } \\
\text { care provided }\end{array}$ & $\begin{array}{l}\text { Median } \\
\text { score }^{+}(I Q R)\end{array}$ & & & & & & & & & & & & \\
\hline $\begin{array}{l}\text { Confidence around raising and } \\
\text { management of safety } \\
\text { concerns }\end{array}$ & $\begin{array}{l}\text { Median } \\
\text { score }^{+}(I Q R)\end{array}$ & & & & & & & & & & & & \\
\hline \multirow[t]{2}{*}{ Moral injury } & No (Ref) & & & & & & & & & & & & \\
\hline & Yes & & & & & & & & & & & & \\
\hline
\end{tabular}

*aOR: adjusted odds ratios - adjusted for age, sex \& ethnicity, and date of survey completion (6-month data also adjusted for corresponding outcome measured at wave 1); $\mathrm{Cl}$ : confidence intervals

${ }^{+}$Scored out of 5 (1=negative ; $5=$ positive) 


\section{References}

1. Dutheil F, Aubert C, Pereira B, et al. Suicide among physicians and health-care workers: $A$ systematic review and meta-analysis. PLoS One 2019; 14(12): e0226361-e.

2. The Lancet. Suicide among health-care workers: time to act. The Lancet 2017; 389(10064): 2.

3. González-Sanguino C, Ausín B, Castellanos MÁ, et al. Mental health consequences during the initial stage of the 2020 Coronavirus pandemic (COVID-19) in Spain. Brain Behav Immun 2020; 87: 172-6.

4. González-Sanguino C, Ausín B, Castellanos MÁ, et al. Mental Health Consequences of the Coronavirus 2020 Pandemic (COVID-19) in Spain. A Longitudinal Study. Frontiers in Psychiatry 2020; 11(1256).

5. Liu $\mathrm{Y}$, Chen $\mathrm{H}$, Zhang $\mathrm{N}$, et al. Anxiety and depression symptoms of medical staff under COVID-19 epidemic in China. Journal of Affective Disorders 2021; 278: 144-8.

6. Serrano-Ripoll MJ, Meneses-Echavez JF, Ricci-Cabello I, et al. Impact of viral epidemic outbreaks on mental health of healthcare workers: a rapid systematic review and meta-analysis. Journal of affective disorders 2020; 277: 347-57.

7. Bell V, Wade D. Mental health of clinical staff working in high-risk epidemic and pandemic health emergencies a rapid review of the evidence and living meta-analysis. Social Psychiatry and Psychiatric Epidemiology 2021; 56(1): 1-11.

8. Lamb D, Gnanapragasam S, Greenberg N, et al. Psychosocial impact of the COVID-19 pandemic on 4378 UK healthcare workers and ancillary staff: initial baseline data from a cohort study collected during the first wave of the pandemic. Occupational and Environmental Medicine 2021.

9. Office for National Statistics. Number of suicides among healthcare workers (persons aged 18 to 64 years) registered in England and Wales during the first six months of 2019 and 2020. 2020.

10. Milner A, Witt K, LaMontagne AD, Niedhammer I. Psychosocial job stressors and suicidality: a meta-analysis and systematic review. Occupational and Environmental Medicine 2018; 75(4): 245. 11. Williamson V, Stevelink SAM, Greenberg N. Occupational moral injury and mental health: systematic review and meta-analysis. The British Journal of Psychiatry 2018; 212(6): 339-46.

12. Arnetz JE, Goetz CM, Sudan S, Arble E, Janisse J, Arnetz BB. Personal Protective Equipment and Mental Health Symptoms Among Nurses During the COVID-19 Pandemic. Journal of Occupational and Environmental Medicine 2020; 62(11).

13. Lamb D, Greenberg N, Hotopf M, et al. NHS CHECK: protocol for a cohort study investigating the psychosocial impact of the COVID-19 pandemic on healthcare workers. BMJ Open 2021; 11(6): e051687.

14. Lewis G, Pelosi AJ, Araya R, Dunn G. Measuring psychiatric disorder in the community: a standardized assessment for use by lay interviewers. Psychol Med 1992; 22 (2): 465-86.

15. Nash WP, Marino Carper TL, Mills MA, Au T, Goldsmith A, Litz BT. Psychometric evaluation of the Moral Injury Events Scale. Mil Med 2013; 178(6): 646-52.

16. West B, Berglund P, Heeringa S. A Closer Examination of Subpopulation Analysis of ComplexSample Survey Data. The Stata Journal 2008; 8: 520 - 31. 


\section{Funding}

Funding for NHS CHECK has been received from the following sources: Medical Research Council (MR/V034405/1); UCL/Wellcome (ISSF3/ H17RCO/C3); Rosetrees (M952); Economic and Social Research Council (ES/V009931/1); as well as seed funding from National Institute for Health Research Maudsley Biomedical Research Centre, King's College London, National Institute for Health Research Health Protection Research Unit in Emergency Preparedness and Response at King's College London.

PP's PhD Clinical Fellowship was funded by the MRC Addiction Research Clinical Training programme [MR/N00616X/1] during the conduct of this study. PM is part-funded by the NIHR Biomedical Research Centre at University Hospitals Bristol and Weston NHS Foundation Trust and the University of Bristol and also receives salary support from Avon \& Wiltshire Mental Health Partnership NHS Trust. DL is supported by the National Institute for Health Research (NIHR) Applied Research Collaborative North Thames (NIHR ARC North Thames). This funder had no role in study design, data collection, data analysis, data interpretation, or writing of the report. The views expressed in this article are those of the authors and not necessarily those of the NHS, the NIHR, or the Department of Health and Social Care.

\section{Acknowledgements}

We wish to acknowledge the National Institute of Health Research (NIHR) Applied Research Collaboration (ARC) National NHS and Social Care Workforce Group, with the following ARCs: East Midlands, East of England, South West Peninsula, South London, West, North West Coast, Yorkshire and Humber, and North East and North Cumbria. They enabled the set-up of the national network of participating hospital sites and aided the research team to recruit effectively during the COVID-19 pandemic.

The NHS CHECK consortium includes the following site leads: Sean Cross, Amy Dewar, Chris Dickens, Mary Docherty, Frances Farnworth, Adam Gordon, Charles Goss, Jessica Harvey, Nusrat Husain, Peter Jones, Damien Longson, Richard Morriss, Jesus Perez, Mark Pietroni, Ian Smith, Tayyeb Tahir, Peter Trigwell, Jeremy Turner, Julian Walker, Scott Weich, Ashley Wilkie.

The NHS CHECK consortium includes the following co-investigators and collaborators: Peter Aitken, Anthony David, Sarah Dorrington, Rosie Duncan, Cerisse Gunasinghe, Stephani Hatch, Daniel Leightley, Ira Madan, Isabel McMullen, Martin Parsons, Paul Moran, Dominic Murphy, Catherine Polling, Alexandra Pollitt, Danai Serfioti, Chloe Simela, Charlotte Wilson Jones.

\section{Competing interests}

SW is an Emeritus NIHR Senior Investigator, and Director of the NIHR PHE Health Protection Research Unit into Emergency Preparedness and Response. This paper represents independent research part-funded by the NIHR Maudsley Biomedical Research Centre Trust and King's College London. SW acknowledges receiving speaker fees for two seminars on "Mental health impacts of COVID-19" for employees of Swiss Re.

The views expressed are those of the authors and not necessarily those of the funders. 